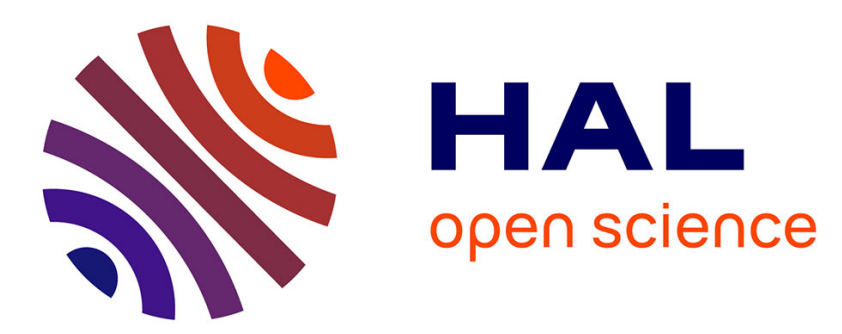

\title{
pH prediction in concentrated aqueous solutions under high pressure of acid gases and high temperature
}

C. Plennevaux, N. Ferrando, J. Kittel, Marion Fregonese, Bernard Normand, T. Cassagne, F. Ropital, M. Bonis

\section{- To cite this version:}

C. Plennevaux, N. Ferrando, J. Kittel, Marion Fregonese, Bernard Normand, et al.. pH prediction in concentrated aqueous solutions under high pressure of acid gases and high temperature. Corrosion Science, 2013, 73, pp.143-149. 10.1016/j.corsci.2013.04.002 . hal-02420555

\section{HAL Id: hal-02420555 \\ https://hal-ifp.archives-ouvertes.fr/hal-02420555}

Submitted on 20 Dec 2019

HAL is a multi-disciplinary open access archive for the deposit and dissemination of scientific research documents, whether they are published or not. The documents may come from teaching and research institutions in France or abroad, or from public or private research centers.
L'archive ouverte pluridisciplinaire HAL, est destinée au dépôt et à la diffusion de documents scientifiques de niveau recherche, publiés ou non, émanant des établissements d'enseignement et de recherche français ou étrangers, des laboratoires publics ou privés. 


\title{
pH prediction in concentrated aqueous solutions under high pressure of acid gases and high temperature
}

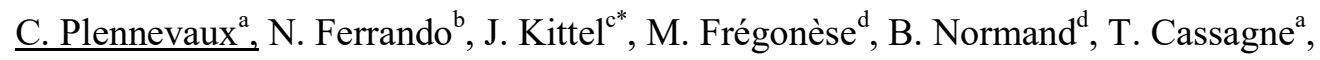 \\ F. Ropital ${ }^{\mathrm{c}}, \mathrm{M}$. Bonis ${ }^{\mathrm{a}}$
}

\author{
${ }^{\text {a }}$ TOTAL, Avenue Larribau, Pau Cedex 64018, France \\ ${ }^{\mathrm{b}}$ IFP Energies nouvelles, 1 et 4 avenue de Bois-Préau, 92852 Rueil-Malmaison, France \\ ${ }^{\mathrm{c}}$ IFP Energies nouvelles, Rond-point de l'échangeur de Solaize BP3, 69360 Solaize, France \\ ${ }^{\mathrm{d}}$ MATEIS, INSA de Lyon, CNRS UMR 5510, Avenue Jean Capelle, Villeurbanne Cedex 69621, \\ France
}

\begin{abstract}
An extended model for $\mathrm{pH}$ prediction in oil and gas environments has been developed. Accurate $\mathrm{pH}$ calculations for high pressure and high temperature applications depends mainly on $\mathrm{CO}_{2}$ and $\mathrm{H}_{2} \mathrm{~S}$ partial pressures, the ionic strength, the chemical composition of the solution, and the temperature. Accounting for the non-ideal behaviors of liquid and gas phases allows $\mathrm{pH}$ calculations up to $200{ }^{\circ} \mathrm{C}$, 2000 bar total pressure, and ionic strengths up to $5 \mathrm{~mol}^{-\mathrm{L}^{-1}}$. The results are consistent with experimental measurements and with other models reported in the literature.
\end{abstract}

Keywords: acid solutions, modeling studies, $\mathrm{pH}, \mathrm{CO}_{2}, \mathrm{H}_{2} \mathrm{~S}$, high pressure, high temperature.

\section{Introduction}

Corrosion of metallic materials in oil and gas wells is strongly influenced by several parameters, among which carbon dioxide $\left(\mathrm{CO}_{2}\right)$ and other corrosive agents as hydrogen sulfide $\left(\mathrm{H}_{2} \mathrm{~S}\right)$ play a central role in controlling the $\mathrm{pH}$. Corrosion prediction models have thus been developed starting several decades ago. While the early model proposed by de Waard and Milliams [1] considered only temperature and $\mathrm{CO}_{2}$ partial pressure, continuous improvements have been made to take into account a greater number of parameters.

The efforts to propose new more accurate models have been shared by oil companies or research institutions, and there is a large number of open or commercial models. A large variety of prediction strategies is found. A comprehensive review was recently issued by Nesic [2], who proposed to classify oil and gas corrosion models in three categories: i/ empirical models are essentially based on correlations with laboratory or field data [3-6]; ii/ mechanistic models require a strong theoretical background. Most parameters have a clear physical meaning, and such models often combine chemical evaluation of the environment, electrochemical reactions, hydrodynamics and precipitation of corrosion products [1,7-21]. Most of these models are proprietary or commercial; iii/ finally, semiempirical models lie in-between the two previous categories. They often contain a part of theoretical calculations, completed by empirical functions calibrated with experimental database [22-26]. The

\footnotetext{
* corresponding author. jean.kittel@ifpen.fr ; +33(0)437702783.
} 
model called Corplus (Model A), developed by some of the authors' company, belongs to the semiempirical type. It is based on a detailed analysis of water chemistry for $\mathrm{pH}$ calculation, and a large amount of corrosion field data.

A comparative study of the performances and limitations of a large number of models was proposed by Nyborg in 2010 [27]. It shed the light on strong limitations of most of these models to temperatures below $150^{\circ} \mathrm{C}$ and acid gas pressure below 70 bar. These limitations were not a problem for typical oil and gas fields operated from the eighties to 2000. However, the number of high pressure (HP) and high temperature (HT) oil and gas fields has considerably increased in the recent years, which cannot be easily treated with common models based on simple assumptions. Various reasons can be found to explain these limitations, depending on the modeling method. As described in details by Nyborg [27], an accurate corrosion prediction relies on several important factors, including in-situ $\mathrm{pH}$ prediction, effect of protective films, effect of oil wetting and connection with fluid flow. Model A was included in the comparative study of Nyborg [27], and is considered to be reliable up to $120{ }^{\circ} \mathrm{C}$ and 20 bar $\mathrm{CO}_{2}$. These limitations are to a great extent associated with the $\mathrm{pH}$ prediction tool which is included in the model.

The goal of this work is therefore to describe the methodology used to extend Model A to HP/HT applications and to highly concentrated brines. The evolution of the model comprises two major steps which are described in this paper: i/ a better description of gases solubility, taking into account the fugacity of gaseous components; ii/ an improvement of chemical equilibria description through the calculation of activity coefficients of species in the liquid phase.

It is then compared to experimental data and to other models from the literature.

\section{Background}

Before presenting the new model in detail, a brief description of the method of $\mathrm{pH}$ calculation used in Model A is proposed. Two groups of reactions are considered: i/ dissolution of acid gases in the aqueous liquid phase and ii/ chemical dissociation of weak acid components [28].

The corresponding reactions are described below.

At the liquid/gas interface, a quantity of $\mathrm{CO}_{2}$ and $\mathrm{H}_{2} \mathrm{~S}$ dissolves in the aqueous solution according to reactions (1) and (2).

$$
\begin{aligned}
\mathrm{CO}_{2(\mathrm{~g})} & \rightleftharpoons \mathrm{CO}_{2(\mathrm{aq})} & S_{\mathrm{CO} 2} \\
\mathrm{H}_{2} \mathrm{~S}_{(\mathrm{g})} & \rightleftharpoons \mathrm{H}_{2} \mathrm{~S}_{(\mathrm{aq})} & S_{\mathrm{H} 2 \mathrm{~S}}
\end{aligned}
$$

In the liquid phase, dissolved carbon dioxide hydrates to carbonic acid following reaction (3).

$$
\mathrm{CO}_{2(\mathrm{aq})}+\mathrm{H}_{2} \mathrm{O} \rightleftharpoons \mathrm{H}_{2} \mathrm{CO}_{3} \quad K_{\text {hyd }}
$$

Carbonic acid and hydrogen sulfide are weak acids. They are likely to dissociate according to reactions (4) to (7).

$$
\begin{aligned}
\mathrm{H}_{2} \mathrm{CO}_{3} & \rightleftharpoons \mathrm{H}^{+}+\mathrm{HCO}_{3}^{-} & & K \\
\mathrm{HCO}_{3}{ }^{-} & \rightleftharpoons \mathrm{H}^{+}+\mathrm{CO}_{3}^{2-} & & K_{2} \\
\mathrm{H}_{2} \mathrm{~S}_{(\mathrm{aq})} & \rightleftharpoons \mathrm{H}^{+}+\mathrm{HS}^{-} & & K_{1}^{\prime} \\
\mathrm{HS}^{-} & \rightleftharpoons \mathrm{H}^{+}+\mathrm{S}^{2-} & & K_{2}^{\prime}
\end{aligned}
$$

The dissolution of acid gases is described by solubility constants $S_{\mathrm{CO} 2}$ and $S_{\mathrm{H} 2 \mathrm{~S}}$ and equilibrium constants $K_{h y d}, K, K_{1}^{\prime}, K_{2}$ and $K_{2}^{\prime}$ define chemical equilibria in the liquid phase. 
Solubility and equilibrium constants depend only on temperature as long as fugacity and activity notions are used. Under ideal conditions, fugacity and activity are equivalent to partial pressure and concentration. However, this assumption cannot be made under high pressure or in highly concentrated solutions. In order to continue to manipulate partial pressures and concentrations, a common practice consists in using apparent solubility and equilibrium constants which include the impact of both the pressure and the ionic strength $(I)$ in addition to the temperature effect. These constants are then expressed as:

$$
\begin{gathered}
S_{i, a p p}(T, P, I)=\frac{c_{i}}{P_{i}} \\
K_{a p p}(T, I)=\prod_{i}\left(c_{i}\right)^{v_{i}}
\end{gathered}
$$

In these expressions, $S_{i, a p p}(T, P, I)$ is the apparent solubility constant of $\mathrm{H}_{2} \mathrm{~S}$ or $\mathrm{CO}_{2}$ in water, $K_{a p p}(T, I)$ is the apparent equilibrium constant of any one of the chemical reactions (3) to (7) and $P_{i}, c_{i}$ and $v_{i}$ are respectively the partial pressure of gas $i$ and the concentration and the stoechiometric coefficient of component $i$ in the liquid phase.

This method is acceptable as long as the apparent constants $S_{i, a p p}$ and $K_{a p p}$ are accurately calculated at given temperature, ionic strength and pressure. The easiest method consists in using empirical expressions as proposed in [6,29-31].

The main difficulty with this approach is to describe the apparent constants with three different variables. Thus, the validity domain is often limited to low pressures, low temperatures and to slightly concentrated brines solutions. In the case of Model A, the limits are $120{ }^{\circ} \mathrm{C}, 20$ bar of $\mathrm{CO}_{2}$ and an ionic strength of $0.75 \mathrm{mol. \textrm {L } ^ { - 1 }}$. In order to extend its range of application, the calculation method of equilibrium constants must be reconsidered taking into account the non-ideal behaviors of the gas and liquid phases. This requires more complete thermodynamics, as described in the next section.

\section{Evolution of the model for HP/HT conditions}

\section{General methodology}

At high pressure, the gas phase cannot be considered as ideal and fugacity correction needs to be applied to account for interactions between gas molecules. As a consequence, three corrections must be applied in the solubility calculations leading to the ensemble Henry's law [32-34] (10):

$$
\gamma_{i} \times c_{i} \times H_{i}(T) \times \exp \left[\int\left(v_{i}^{\infty} / R T\right) \mathrm{d} P\right]=\Phi_{i} \times P_{i}
$$

In this expression, $c_{i}$ is the concentration of component $i$ in the liquid phase, $H_{i}(T)$ is the Henry's constant characterizing the solubility of gas $i$ in water and $P_{i}$ is the partial pressure of component $i$. The activity coefficient $\gamma_{i}$ accounts for non-ideality of dissolved gas, the exponential term is known as the Poynting correction $[32,33]$ considering the effect of high pressures on the partial molar volume of the solute under infinite dilution $\left(v_{i}^{\infty}\right)$ and the fugacity coefficient $\Phi_{i}$ corrects the gas phase for nonideal behavior.

Similarly, reactions in concentrated solutions are influenced by interactions between dissolved molecules and ions. To consider the non-ideal behavior of the liquid phase, the calculation of chemical equilibrium constants must also be corrected adding activity coefficients (11):

$$
K(T)=\prod_{i}\left(a_{i}\right)^{v_{i}}=\prod_{i}\left(\gamma_{i} \times c_{i}\right)^{v_{i}}
$$


In this expression, $K(T)$ is the equilibrium constant of one of the chemical reactions (3) to (7), $a_{i}, c_{i}$ and $\gamma_{i}$ are respectively the activity, the concentration and the activity coefficient of component $i$ in the liquid phase and $v_{i}$ is the stoechiometric coefficient of component $i$ for the chemical equilibrium considered.

In order to make the model modification as simple as possible, we simply replaced the empirical expressions of solubility constants and chemical equilibrium constants used in Model A by new expressions derived from (10) and (11), according to respectively (12) and (13):

$$
\begin{gathered}
S_{i, a p p}(T, P, I)=\frac{\Phi_{i}}{\gamma_{i} \times H_{i}(T) \times \exp \left[\int\left(v_{i}^{\infty} / R T\right) \mathrm{d} P\right]}=\frac{c_{i}}{P_{i}} \\
K_{a p p}(T, I)=K(T) \times \prod_{i}\left(\gamma_{i}\right)^{-v_{i}}=\prod_{i}\left(c_{i}\right)^{v_{i}}
\end{gathered}
$$

\section{Determination of true Henry's constants and chemical equilibrium constants}

$\mathrm{CO}_{2}$ and $\mathrm{H}_{2} \mathrm{~S}$ Henry's constant values used in Equation (12) are determined with the correlation proposed by de Hemptinne et al. as:

$$
\ln \left(H_{i}(T)\right)=A_{i}+\frac{B_{i}}{T}+\frac{C_{i}}{T^{2}}
$$

where $H_{i}(T)$ is the Henry's constant on the mole fraction scale characterizing the solubility of gas $i$ in water, $T$ is the temperature $(\mathrm{K})$ and $A_{i}, B_{i}$ and $C_{i}$ have the values given in Table 1 [35].

This expression was established from experimental databases covering temperature range from $20{ }^{\circ} \mathrm{C}$ to $200^{\circ} \mathrm{C}$.

Chemical equilibrium constants $K(T)$ were also determined from correlations presented in the literature [36-40].

\section{Fugacity coefficients of gaseous components}

The Soreide and Whitson [41] modification of the Peng-Robinson equation of state (EOS) [42] is used for describing the fugacity of $\mathrm{CO}_{2}, \mathrm{H}_{2} \mathrm{~S}, \mathrm{H}_{2} \mathrm{O}$ and $\mathrm{CH}_{4}$ in the gas phase. Thus the effect of high pressure of natural gas on acid gas fugacity is included in the calculations.

The Peng-Robinson EOS (15) is derived from Van der Waals theory:

$$
P=\frac{R T}{v-b}-\frac{a(T)}{v(v+b)+b(v-b)}
$$

In this expression, the pressure is calculated as a function of a repulsive term taking into account the co-volume $b$ and a parameter $a$ regarded as a measure of intermolecular attraction forces. This parameter depends on temperature. $R$ is the gas constant, $T$ is the temperature (K), $P$ the total pressure $(\mathrm{Pa})$ and $v$ the molar volume $\left(\mathrm{m}^{3} \cdot \mathrm{mol}^{-1}\right)$.

Peng and Robinson used this equation to express the fugacity coefficient $\Phi_{i}$ of a component $i$ in a mixture [42]: 


$$
\ln \left(\Phi_{i}\right)=\frac{b_{i}}{b}(Z-1)-\ln (Z-B)-\frac{A}{2 \sqrt{2} B}\left(\frac{2 \sum_{j} x_{j} a_{j i}}{a}-\frac{b_{i}}{b}\right) \ln \left(\frac{Z+2.414 B}{Z-0.414 B}\right)
$$

where $A=\frac{a P}{R^{2} T^{2}}, B=\frac{b P}{R T}$ and $Z=\frac{P v}{R T}$

In this expression, $x_{i}$ is the mole fraction of component $i, b_{i}$ is the co-volume of component $i, a_{j i}$ characterizes the binary system formed by components $j$ and $i$. SI units are used in this equation.

The presence of salts in the formation water also has a great influence on gas solubility, which is not directly taken into account by the Peng and Robinson expression. Thus, Soreide and Whitson have proposed an extension of the Peng-Robinson EOS for treating the case of water-hydrocarbon mixtures in the presence of sodium chloride in the water phase. One of the main changes consists in a modification of the attractive term of pure water.

Equation (16) was used in this study for the calculation of gases fugacity coefficients, using constant parameters values from reference [35].

\section{Activity coefficients in the liquid phase}

The calculation of activity coefficients of components in the liquid phase was performed applying Pitzer's model $[43,44]$ which derives from Debye-Hückel's method. This activity model is adapted to describe thermodynamic properties of concentrated brines solutions.

Debye-Hückel's equations give an expression of activity coefficients of ionic species from the ionic strength of the solution. This method takes into account long distance interactions between ionic species corresponding to electrostatic interactions. This approach is valid for slightly concentrated solutions (maximum molality of salts of about $1 \mathrm{~mol} \cdot \mathrm{kg}^{-1}$ of water).

To adapt the activity model to highly concentrated brines, Pitzer has added short distance interaction terms to the Debye-Hückel's model corresponding to interactions between ionic species and the solvent.

The formalism of Pitzer's model will not be detailed in this paper. However, Table 2 summarizes all binary and ternary interaction parameters that we considered in our system, considering dissolved $\mathrm{CO}_{2}$ and $\mathrm{H}_{2} \mathrm{~S}$ and the following ionic species: $\mathrm{Ca}^{2+}, \mathrm{Na}^{+}, \mathrm{Cl}^{-}, \mathrm{H}^{+}, \mathrm{HCO}_{3}^{-}, \mathrm{CO}_{3}{ }^{2-}, \mathrm{HS}^{-}, \mathrm{S}^{2-}$ and $\mathrm{HO}^{-}$.

\section{Validity domain, capabilities and limitations of the new model}

At the present time, the new model only applies to $\mathrm{CO}_{2}, \mathrm{H}_{2} \mathrm{~S}, \mathrm{CH}_{4}$ and $\mathrm{H}_{2} \mathrm{O}$ for the gas phase. In the liquid phase, ionic species that are considered for calculations of activity coefficients are $\mathrm{Ca}^{2+}, \mathrm{Na}^{+}, \mathrm{Cl}^{-}$ , $\mathrm{H}^{+}, \mathrm{HCO}_{3}^{-}, \mathrm{CO}_{3}{ }^{2-}, \mathrm{HS}^{-}, \mathrm{S}^{2-}$ and $\mathrm{HO}^{-}$. The main input parameters of the model are: total pressure and partial pressures of $\mathrm{CO}_{2}, \mathrm{H}_{2} \mathrm{~S}$ and $\mathrm{CH}_{4}$, temperature and ionic composition of the solution $\left(\mathrm{Ca}^{2+}, \mathrm{Na}^{+}\right.$, $\mathrm{Cl}^{-}, \mathrm{HCO}_{3}^{-}$). The main output data are: in-situ $\mathrm{pH}$, the fugacity of gases, the concentration and the activity of all species in the liquid aqueous phase.

Precipitation of solids is not considered and acetate ions are also not included in the new model. It is a perspective of this work to include acetate anions and iron cations parameters in Pitzer's formulation.

As a first approximation, the validity domain can be estimated from the validity of individual elements used in the new model. The main limitations arise from the validity domains of equilibrium constants and of interaction parameters; we can thus expect good predictions up to $200{ }^{\circ} \mathrm{C}, 1000$ bar total pressure, and ionic strengths up to $5 \mathrm{~mol} . \mathrm{L}^{-1}$. However, the availability of experimental data for model validation does not cover this domain completely. A discussion of the validity domain based on comparisons with experimental data and other models is thus given in the next section of this paper. 


\section{Results and discussion}

Only a few published papers were found with $\mathrm{pH}$ measurements at high pressure, high temperature and high salinity. None of them covered at the same time the expected validity domain of our new model. Thus, analysis of the new model capabilities could only be performed for one or two parameters at a time.

A selection of comparisons between the new model predictions and data from the literature is provided from Figure 1 to Figure 5. Comparisons with other models freely available or reported in the literature were also performed. A detailed list of these models is given in Table 3. Model A refers to Corplus, which has a known validity domain consisting of $120^{\circ} \mathrm{C}, 20$ bar of $\mathrm{CO}_{2}$ and ionic strength below 0.75 mol. $L^{-1}$. Model $\mathrm{A}_{\mathrm{fc}}$ is a modified use of Model A, using the fugacity of $\mathrm{CO}_{2}$ and $\mathrm{H}_{2} \mathrm{~S}$ as input instead of partial pressures (fugacity coefficients were calculated by the Soreide and Whitson's model [41]). Model B was taken from a paper by Duan and Sun [51] with an approach based on Pitzer's theory and an equation of state for fugacity calculations, very similar to our new model. Model C and D consist in $\mathrm{pH}$ calculation models by Shell and BP respectively, with calculated values taken from [56]. Model E refers to the freely available Norsok Model [6], which can be used at temperature between 5 and $150{ }^{\circ} \mathrm{C}$, ionic strength comprised between 0 and 3 mol. $\mathrm{L}^{-1}$, and $\mathrm{CO}_{2}$ fugacity from 0.1 to 10 bar.

\section{Solubility predictions}

Once Soreide and Whitson's model and Pitzer's model provide respectively the fugacity and activity coefficients of components in the gas phase and in the liquid phase, the Ensemble Henry's law (10) is applied to assess the solubility of $\mathrm{H}_{2} \mathrm{~S}$ and $\mathrm{CO}_{2}$ in different conditions.

Note that in the proposed approach, we do not perform a rigorous thermodynamic flash calculation, since the fugacity equality constraint in both phases is not checked for water. It is a limitation of this approach, but the results presented further show that this approximation does not significantly affect the accuracy of the model in the considered temperature and pressure ranges.

The predictions of the new model for $\mathrm{H}_{2} \mathrm{~S}$ solubility in pure water were compared to $\mathrm{Ng}$ et al. [57] experimental data. These authors performed measurements of $\mathrm{H}_{2} \mathrm{~S}$ solubility in water in the case of different $\mathrm{CH}_{4} / \mathrm{C}_{3} \mathrm{H}_{8} / \mathrm{H}_{2} \mathrm{~S} / \mathrm{CO}_{2}$ gas mixtures at various temperatures. Figure 1 shows the concentration of dissolved $\mathrm{H}_{2} \mathrm{~S}$ versus the total pressure of $75 \% \mathrm{CH}_{4}-\mathrm{C}_{3} \mathrm{H}_{8}\left(95: 5\right.$ mole ratio) and $25 \% \mathrm{H}_{2} \mathrm{~S}-\mathrm{CO}_{2}(3: 1$ mole ratio). The calculation of fugacity coefficients of gases was performed assuming propane to show similar interactions properties like methane with the others components. The new model gives more accurate predictions of $\mathrm{H}_{2} \mathrm{~S}$ solubility with this set of experimental data than models $\mathrm{A}$ and $\mathrm{A}_{\mathrm{fc}}$.

The predictions of the new model for $\mathrm{CO}_{2}$ solubility were compared to Rumpf et al. [58] experimental data. These authors measured $\mathrm{CO}_{2}$ solubility in highly concentrated $\mathrm{NaCl}$ solutions under pressure of pure $\mathrm{CO}_{2}$ at different temperatures. Figure 2 shows the concentration of dissolved $\mathrm{CO}_{2}$ in 4 mol. $\mathrm{kg}^{-1}$ $\mathrm{NaCl}$ solutions versus the total pressure at $40{ }^{\circ} \mathrm{C}$ and $160{ }^{\circ} \mathrm{C}$. On Figure 3, the prediction of the new model were also compared to another model proposed in the literature (Model B) [51] and to Takenouchi et al. experimental data [59] obtained in $\mathrm{NaCl}$ solutions $\left(1 \mathrm{~mol} . \mathrm{L}^{-1}\right.$ and 4 mol. $\left.\mathrm{L}^{-1}\right)$ at 200 ${ }^{\circ} \mathrm{C}$ up to 1400 bar of $\mathrm{CO}_{2}$. The new model presents a good agreement with these solubility data, even in a highly concentrated solution and on a wide range of temperature and pressure, whereas model $\mathrm{A}$ presents significant error at high pressure $\mathrm{CO}_{2}$, even after fugacity corrections (model $\mathrm{A}_{\mathrm{fc}}$ ). The predictions of the new model are extremely close to those obtained with Model B [51].

For highly concentrated brine solutions, these results show that the application of the ensemble Henry's law combining Dhima's constants, Soreide and Whitson's model and Pitzer's model provides accurate predictions of $\mathrm{CO}_{2}$ and $\mathrm{H}_{2} \mathrm{~S}$ solubilities even under high temperature, high pressure. It is therefore appropriate for in-situ $\mathrm{pH}$ calculation, as detailed in the next part of the paper. 


\section{pH predictions}

The calculation method of $\mathrm{pH}$ is classically derived from the electroneutrality equation as described elsewere [28]. Once $\mathrm{H}^{+}$concentration is determined, $\mathrm{pH}$ is calculated from $\mathrm{H}^{+}$activity according to:

$$
p H=-\log a_{H^{+}}=-\log \left(\gamma_{H^{+}} \times c_{H^{+}}\right)
$$

In this expression, $a_{H^{+}}$is the activity of $\mathrm{H}^{+}, \gamma_{H^{+}}$is the activity coefficient of $\mathrm{H}^{+}$and $c_{H^{+}}$is the concentration of $\mathrm{H}^{+}$in water.

Comparisons with different sets of experimental data are presented on Figure 4 and Figure 5.

Figure 4 illustrates the impact of $\mathrm{NaCl}$ concentration on $\mathrm{pH}$. Experimental data was obtained at $25^{\circ} \mathrm{C}$ and 1 bar $\mathrm{CO}_{2}$ by Hinds et al. [56]. In the same paper, these authors compared the prediction of two models of oil and gas companies (Model $\mathrm{C}$ and $\mathrm{D}$ ). The new model predicts the experimental results within less than $0.05 \mathrm{pH}$ unit in the whole range of $\mathrm{NaCl}$ concentration from zero to more than 4 mol. $\mathrm{L}^{-1}$ and gives similar results to Model $\mathrm{C}$ and Model D. On the other hand, Model A tends to underestimate the $\mathrm{pH}$ value for $\mathrm{NaCl}$ concentration below 1 mol. $\mathrm{L}^{-1}$.

Figure 5 shows $\mathrm{pH}$ values in pure water under $\mathrm{CO}_{2}$ pressure up to 350 bar. Experimental data was obtained by Meyssami et al. [60] in autoclave. The new model reproduces the $\mathrm{pH}$ evolution with a good accuracy in all $\mathrm{P}_{\mathrm{CO} 2}$ domain. For comparison, calculations were also performed with Model A after fugacity correction (Model $\mathrm{A}_{\mathrm{fc}}$ ), and with the Norsok model (Model E, [6]). They both give acceptable $\mathrm{pH}$ values up to 50 to 100 bar $\mathrm{CO}_{2}$.

Although no experimental data of $\mathrm{pH}$ measurements were found above 350 bar of acid gases, the prediction of the model was evaluated up to 2000 bar $\mathrm{CO}_{2}$ in conditions similar to Figure 3. The results are displayed on Figure 6. It appears that above a few hundred bars of $\mathrm{CO}_{2}$, the $\mathrm{pH}$ value hardly decreases, mainly due to fugacity coefficient evolution. It also appears that at constant $\mathrm{NaCl}$ concentration and $\mathrm{CO}_{2}$ partial pressure, $\mathrm{pH}$ increases with increasing temperature. This evolution is mainly due to the decrease of $\mathrm{CO}_{2}$ solubility at higher temperature. Finally, for the two temperature values chosen for this example i.e. $40{ }^{\circ} \mathrm{C}$ and $200{ }^{\circ} \mathrm{C}$, we observe a different impact of $\mathrm{NaCl}$ concentration. At $200{ }^{\circ} \mathrm{C}$, the calculated $\mathrm{pH}$ hardly varies when $\mathrm{NaCl}$ concentration increases from 1 to 4 mol. $\mathrm{L}^{-1}$. On the contrary, at $40^{\circ} \mathrm{C}$, increasing $\mathrm{NaCl}$ concentration results in a significant decrease of $\mathrm{pH}$, as already illustrated in Figure 4 at $25^{\circ} \mathrm{C}$.

\section{Discussion on the validity domain}

Two levels of validity domain were considered.

The first one is based only on the theoretical validity domain of the different equations used, mostly from Pitzer's model, as well as Soreide and Witson [41]. Pitzer's model was specially developed for highly concentrated electrolytes. It is thus often reported that the equations provides accurate results up to 5 to $6 \mathrm{~mol} \cdot \mathrm{L}^{-1}$ and that the equation of state for fugacity calculations is usually applicable up to 1000 bar of total pressure [61]. However, the validity domain also depends on the knowledge of Pitzer's parameters and on the accuracy of correlations chosen for equilibrium constants calculations. Considering our application, the parameters and correlations found in the literature suggest that the temperature limit is $200{ }^{\circ} \mathrm{C}$.

The second level of validity domain which is considered is based on comparisons with experimental data. Due to the difficulty of making experiments at extremely high pressure and temperature, the range of pressure, temperature and ionic strength is narrower than the theoretical validity domain. As shown in Table 4, $\mathrm{pH}$ prediction of the new model could be compared with experimental data only up 
to 350 bar, $42{ }^{\circ} \mathrm{C}$ and $4.25 \mathrm{~mol} . \mathrm{L}^{-1}$. Solubility prediction benefits from more published data, and the validity could thus be checked up to $1400 \mathrm{bar}, 200^{\circ} \mathrm{C}$ and $4 \mathrm{~mol} . \mathrm{L}^{-1}$.

These different validity domains are illustrated on Figure 7.

\section{Conclusion}

The in-situ $\mathrm{pH}$ of formation water is one of the most important parameters for material selection in the oil and gas production. Most prediction tools currently employed were designed in the $80 \mathrm{~s}$ and were adapted to temperatures lower than $150{ }^{\circ} \mathrm{C}$, maximum pressures of 50 bar and slightly concentrated solutions (up to $1 \mathrm{~mol} \cdot \mathrm{L}^{-1}$ ).

However, the increasing interest of HP/HT fields requires more accurate models with extended validity domain. For this purpose, we applied a calculation method based on the ensemble Henry's law for solubility calculations and taking into account the activity of chemical species for chemical equilibrium constants calculation.

Extension of the current model used by the authors was described. It uses fugacity coefficients calculated with Soreide and Whitson's model. The effect of high concentrations of salts on the activity of chemical species in the liquid phase is modeled using Pitzer's formalism.

Even though only sparse experimental data is available in the literature at high temperature, high pressure and in concentrated solutions, all comparisons between the new model and the measurements gave a good agreement. New calculations are usually less conservative than the former ones, with higher $\mathrm{pH}$ values and lower $\mathrm{H}_{2} \mathrm{~S}$ activity. Using such models allows more accurate $\mathrm{pH}$ and $\mathrm{H}_{2} \mathrm{~S}$ fugacity predictions, with potential impacts on fit-for-purpose testing.

\section{References}

[1] C. de Waard, D.E. Milliams, Carbonic-acid corrosion of steel, Corrosion 31 (1975) 177-181.

[2] S. Nesic, Key issues related to modelling of internal corrosion of oil and gas pipelines - A review, Corros. Sci. 49 (2007) 4308-4338.

[3] A. Dugstad, L. Lunde, K. Videm, Parametric study of $\mathrm{CO}_{2}$ corrosion of carbon steel, Corrosion/94 paper no. 14, NACE International, Houston, TX, 1994.

[4] A.M.K. Halvorsen, T. Sontvedt, $\mathrm{CO}_{2}$ corrosion model for carbon steel including a wall shear stress model for multiphase flow and limits for production rate to avoid mesa attack, Corrosion/99 paper no. 42, NACE International, Houston, TX, 1999.

[5] S. Nesic, J. Postlethwaite, M. Vrhovac, $\mathrm{CO}_{2}$ corrosion of carbon steel - from mechanistic to empirical modelling, Corros. Rev. 15 (1997) 211-240.

[6] NORSOK standard M-506, $\mathrm{CO}_{2}$ corrosion rate calculation model, Standards Norway, Lysaker, Norway, 2005.

[7] A. Anderko, R.D. Young, Simulation of $\mathrm{CO}_{2} / \mathrm{H}_{2} \mathrm{~S}$ corrosion using thermodynamic and electrochemical models, Corrosion/99 paper no. 31, NACE International, Houston, TX, 1999.

[8] A. Anderko, P. McKenzie, R.D. Young, Computation of rates of general corrosion using electrochemical and thermodynamic models, Corrosion 2000 paper no. 479, NACE International, Houston, TX, 2000.

[9] A. Anderko, R.D. Young, A model for calculating the rates of general corrosion of carbon steel and $13 \% \mathrm{Cr}$ stainless steels in $\mathrm{CO}_{2} / \mathrm{H}_{2} \mathrm{~S}$ environments, Corrosion 2001 paper no. 86, NACE International, Houston, TX, .

[10] E. Dayalan, G. Vani, J.R. Shadley, S.A. Shirazi, E.F. Rybicki, Modeling $\mathrm{CO}_{2}$ corrosion of carbon steels in pipe flow, Corrosion/95 paper no. 118, NACE International, Houston, TX, 1995. 
[11] E. Dayalan, F. De Moraes, J.R. Shadley, S.A. Shirazi, E.F. Rybicki, $\mathrm{CO}_{2}$ corrosion prediction in pipe flow under $\mathrm{FeCO}_{3}$ scale-forming conditions, Corrosion/98 paper no. 51, NACE International, Houston, TX, 1998.

[12] S. Nesic, J. Postlethwaite, S. Olsen, An electrochemical model for prediction of corrosion of mild steel in aqueous carbon dioxide solutions, Corrosion, 52 (1996) 280-294.

[13] S. Nesic, M. Nordsveen, R. Nyborg, A. Stangeland, A mechanistic model for carbon dioxide corrosion of mild steel in the presence of protective iron carbonate films - Part 2: A numerical experiment, Corrosion, 59 (2003) 489-497.

[14] S. Nesic, S. Wang, J. Cai, Y. Xiao, Integrated $\mathrm{CO}_{2}$ corrosion - Multiphase flow model, Corrosion 2004 paper no. 626, NACE International, Houston, TX, 2004.

[15] S. Nesic, J. Cai, K.L.J. Lee, A multiphase flow and internal corrosion prediction model for mild steel pipelines, Corrosion 2005 paper no. 556, NACE International, Houston, TX, 2005.

[16] S. Nesic, S. Wang, H. Fang, W. Sun, K.L.J. Lee, A New updated model of $\mathrm{CO}_{2} / \mathrm{H}_{2} \mathrm{~S}$ corrosion in multiphase flow, Corrosion 2008 paper no.535, NACE International, Houston, TX, 2008.

[17] M. Nordsveen, S. Nesic, R. Nyborg, A. Stangeland, A mechanistic model for carbon dioxide corrosion of mild steel in the presence of protective iron carbonate films - Part 1: Theory and verification, Corrosion, 59 (2003) 443-456.

[18] B.F.M. Pots, Mechanistic models for the prediction of $\mathrm{CO}_{2}$ corrosion rates under multi-phase flow conditions, Corrosion/95 paper no. 137, NACE International, Houston, TX, 1995.

[19] B.F.M. Pots, R.C. John, I.J. Rippon, M.J.J.S. Thomas, S.D. Kapusta, M.M. Girgis, T. Whitham, Improvements on De Waard - Milliams corrosion prediction and applications to corrosion management, Corrosion 2002 paper no. 235, NACE International, Houston, TX, 2002.

[20] B.F.M. Pots, S.D. Kapusta, Prediction of corrosion rates of the main corrosion mechanisms in upstream applications, Corrosion 2005 paper no. 550, NACE International, Houston, TX, 2005.

[21] N. Sridhar, D.S. Dunn, A.M. Anderko, M.M. Lencka, H.U. Schutt, Effects of water and gas compositions on the internal corrosion of gas pipelines - Modeling and experimental studies, Corrosion, 57 (2001) 221-235.

[22] M.R. Bonis, J.L. Crolet, Basics of the prediction of the risks of $\mathrm{CO}_{2}$ corrosion in oil and gas wells, Corrosion/89 paper no. 466, NACE International, Houston, TX, 1989.

[23] J.L. Crolet, M.R. Bonis, Prediction of the risks of $\mathrm{CO}_{2}$ corrosion in oil and gas well, SPE Prod. Eng. 6 (1991) 449-453.

[24] C. de Waard, U. Lotz, Prediction of $\mathrm{CO}_{2}$ corrosion of carbon steel, Corrosion/93 paper no. 69, NACE International, Houston, TX, 1993.

[25] C. de Waard, U. Lotz, A. Dugstad, Influence of liquid flow velocity on $\mathrm{CO}_{2}$ corrosion: A semiempirical model, Corrosion/95 paper no. 128, NACE International, Houston, TX, 1995.

[26] Y.M. Gunaltun, Combining research and field data for corrosion rate prediction, Corrosion/96 paper no. 27, NACE International, Houston, TX, 1996.

[27] R. Nyborg, $\mathrm{CO}_{2}$ corrosion models for oil and gas production systems, Corrosion 2010 paper no. 371, NACE International, Houston, TX, 2010.

[28] J.L. Crolet, M.R. Bonis, pH measurements under high-pressures of $\mathrm{CO}_{2}$ and $\mathrm{H}_{2} \mathrm{~S}$, Mater. Performance, 23 (1984) 35-42.

[29] J.E. Oddo, M.B. Tomson, Simplified calculation of $\mathrm{CaCO}_{3}$ saturation at high-temperatures and pressures in brine solutions, J. Petrol. Tech. 34 (1982) 1583-1590.

[30] D.A. Palmer, R. Van Eldik, The chemistry of metal carbonato and carbon dioxide complexes, Chem. Rev. 83 (1983) 651-731.

[31] W. Sun, Kinetics of iron carbonate and iron sulfide scale formation in $\mathrm{CO}_{2} / \mathrm{H}_{2} \mathrm{~S}$ corrosion, $\mathrm{PhD}$ thesis, Ohio University, Athens, OH, 2006.

[32] J.J. Carroll, What is Henry's law?, Chem. Eng. Prog. 87 (1991) 48-52.

[33] J.L. Nelson, R.V. Reddy, Selecting representative laboratory test conditions for fit-for-purpose OCTG material evaluations, SPE High Pressure / High Temperature Sour Well Design Applied Technology Workshop paper no. 97576, The Woodlands, TX, 2005.

[34] M.F. Mohamed, A.M. Nor, M.F. Suhor, M. Singer, Y.S. Choi, S. Nesic, Water chemistry for corrosion prediction in high pressure $\mathrm{CO}_{2}$ environments, Corrosion (2011) (paper no. 375). 
[35] J.C. De Hemptinne, A. Dhima, S. Shakir, The Henry constant for 20 hydrocarbons, $\mathrm{CO}_{2}$ and $\mathrm{H}_{2} \mathrm{~S}$ in water as a function of pressure and temperature, Fourteenth symposium on Thermophysical Properties, Boulder, CO, 2000.

[36] D.M. Austgen, G.T. Rochelle, C.C. Chen, Model of vapor-liquid-equilibria for aqueous acid gas-alkanolamine systems . 2. Representation of $\mathrm{H}_{2} \mathrm{~S}$ and $\mathrm{CO}_{2}$ solubility in aqueous MDEA and $\mathrm{CO}_{2}$ solubility in aqueous mixtures of MDEA with MEA or DEA, Ind. Eng. Chem. Res. 30 (1991) 543-555.

[37] F.J. Millero, The thermodynamics and kinetics of the hydrogen-sulfide system in natural-waters, Mar. Chem. 18 (1986) 121-147.

[38] G. Olofsson, L.G. Hepler, Thermodynamics of ionization of water over wide ranges of temperature and pressure, J. Solution Chem. 4 (1975) 127-143.

[39] C.S. Patterson, G.H. Slocum, R.H. Busey, R.E. Mesmer, Carbonate equilibria in hydrothermal systems: First ionization of carbonic acid in $\mathrm{NaCl}$ media to $300{ }^{\circ} \mathrm{C}$, Geochim. Cosmochim. Acta, 46 (1982) 1653-1663.

[40] J.C. Peiper, K.S. Pitzer, Thermodynamics of aqueous carbonate solutions including mixtures of sodium-carbonate, bicarbonate, and chloride, J. Chem. Thermodyn. 14 (1982) 613-638.

[41] I. Soreide, C.H. Whitson, Peng-Robinson predictions for hydrocarbons, $\mathrm{CO}_{2}, \mathrm{~N}_{2}$, and $\mathrm{H}_{2} \mathrm{~S}$ with pure water and $\mathrm{NaCl}$ brine, Fluid Phase Equilib. 77 (1992) 217-240.

[42] D.Y. Peng, D.B. Robinson, A new two-constant equation of state, Ind. Eng. Chem. Fundam. 15 (1976) 59-64.

[43] K.S. Pitzer, J.C. Peiper, R.H. Busey, Thermodynamic properties of aqueous sodium-chloride solutions, J. Phys. Chem. Ref. Data 13 (1984) 1-102.

[44] K.S. Pitzer, Thermodynamics of electrolytes. I. Theoretical basis and general equations, J. Phys. Chem. 77 (1973) 268-277.

[45] H.F. Holmes, R.H. Busey, J.M. Simonson, R.E. Mesmer, D.G. Archer, R.H. Wood, The enthalpy of dilution of $\mathrm{HCl}(\mathrm{aq})$ to $648 \mathrm{~K}$ and $40 \mathrm{MPa}$ thermodynamic properties, J. Chem. Thermodyn. 19 (1987) 863-890.

[46] J.P. Greenberg, N. Moller, The prediction of mineral solubilities in natural waters: A chemical equilibrium model for the Na-K-Ca-Cl- $\mathrm{SO}_{4}-\mathrm{H}_{2} \mathrm{O}$ system to high concentration from 0 to $250{ }^{\circ} \mathrm{C}$, Geochim. Cosmochim. Acta 53 (1989) 2503-2518.

[47] Z.H. Duan, D.D. Li, Coupled phase and aqueous species equilibrium of the $\mathrm{H}_{2} \mathrm{O}-\mathrm{CO}_{2}-\mathrm{NaCl}-$ $\mathrm{CaCO}_{3}$ system from 0 to 250 degrees $\mathrm{C}, 1$ to 1000 bar with $\mathrm{NaCl}$ concentrations up to saturation of halite, Geochim. Cosmochim. Acta 72 (2008) 5128-5145.

[48] C.E. Harvie, N. Moller, J.H. Weare, The prediction of mineral solubilities in natural waters: The $\mathrm{Na}-\mathrm{K}-\mathrm{Mg}-\mathrm{Ca}-\mathrm{H}-\mathrm{Cl}-\mathrm{SO}_{4}-\mathrm{OH}-\mathrm{HCO}_{3}-\mathrm{CO}_{3}-\mathrm{CO}_{2}-\mathrm{H}_{2} \mathrm{O}$ system to high ionic strengths at $25{ }^{\circ} \mathrm{C}$, Geochim. Cosmochim. Acta 48 (1984) 723-751.

[49] F. Millero, F. Huang, T. Graham, D. Pierrot, The dissociation of carbonic acid in $\mathrm{NaCl}$ solutions as a function of concentration and temperature, Geochim. Cosmochim. Acta 71 (2007) 46-55.

[50] R.T. Pabalan, K.S. Pitzer, Thermodynamics of $\mathrm{NaOH}(\mathrm{aq})$ in Hydrothermal Solutions, Geochim. Cosmochim. Acta 51 (1987) 829-837.

[51] Z. Duan, R. Sun, An improved model calculating $\mathrm{CO}_{2}$ solubility in pure water and aqueous $\mathrm{NaCl}$ solutions from 273 to $533 \mathrm{~K}$ and from 0 to 2000 bar, Chem. Geol. 193 (2003) 257-271.

[52] F. Kurz, B. Rumpf, G. Maurer, Vapor-liquid-solid equilibria in the system $\mathrm{NH}_{3}-\mathrm{CO}_{2}-\mathrm{H}_{2} \mathrm{O}$ from around 310 to $470 \mathrm{~K}$ : New experimental data and modeling, Fluid Phase Equilib. 104 (1995) 261-275.

[53] H. Carrier, Contribution à l'étude thermodynamique de solutions d'électrolytes sous haute pression, haute température, PhD thesis, Université de Pau, Pau (France), 1996.

[54] J. Xia, A. Perez-Salado Kamps, B. Rumpf, G. Maurer, Solubility of hydrogen sulfide in aqueous solutions of single strong electrolytes sodium nitrate, ammonium nitrate, and sodium hydroxide at temperatures from 313 to $393 \mathrm{~K}$ and total pressures up to $10 \mathrm{MPa}$, Fluid Phase Equilib. 167 (2000) 263-284.

[55] S. He, J.W. Morse, The carbonic acid system and calcite solubility in aqueous Na-K-Ca-Mg-Cl$\mathrm{SO}_{4}$ solutions from 0 to $90^{\circ} \mathrm{C}$, Geochim. Cosmochim. Acta 57 (1993) 3533-3554.

[56] G. Hinds, P. Cooling, A. Wain, S. Zhou, A. Turnbull, Technical note: Measurements of pH in concentrated brines, Corrosion 65 (2009) 635-702. 
[57] H.-J. Ng, C.-J. Chen, H. Schroeder. Water content of natural gas systems containing acid gas, Gas Processors Association (GPA) project no. 945, research report RR-174, 2001.

[58] B. Rumpf, H. Nicolaisen, C. Ocal, G. Maurer, Solubility of carbon-dioxide in aqueous-solutions of sodium-chloride - Experimental results and correlation, J. Solution Chem. 23 (1994) 431448.

[59] S. Takenouchi, G.C. Kennedy, The solubility of carbon dioxide in $\mathrm{NaCl}$ solutions at high temperatures and pressures. Am. J. Sci. 263 (1965) 445-454.

[60] B. Meyssami, M.O. Balaban, A.A. Teixeira, Prediction of $\mathrm{pH}$ in model systems pressurized with carbon-dioxide, Biotechnol. Progr. 8 (1992) 149-154.

[61] N. Ferrando, R. Lugo, P. Mougin, Coupling activity coefficient models, Henry constant equations, and equation of state to calculate vapor-liquid and solid-liquid equilibrium data, Chem. Eng. Process. 45 (2006) 773-782. 


\section{Figures}

Figure 1: $\mathrm{H}_{2} \mathrm{~S}$ solubility in pure water versus total pressure of a $75 \% \mathrm{CH}_{4}-\mathrm{C}_{3} \mathrm{H}_{8}(95: 5$ mole ratio) and 25\% $\mathrm{H}_{2} \mathrm{~S}-\mathrm{CO}_{2}$ (3:1 mole ratio) gas mixture at $49{ }^{\circ} \mathrm{C}$. Comparison of the new model predictions to experimental data [57] and to Model A and fugacity-corrected Model A (Model $\mathbf{A}_{\text {fc }}$ ).

Figure 2: $\mathrm{CO}_{2}$ solubility in 4 mol.kg- ${ }^{-1} \mathrm{NaCl}$ solution versus $\mathrm{CO}_{2}$ partial pressure at $40{ }^{\circ} \mathrm{C}$ and $160{ }^{\circ} \mathrm{C}$. Comparison of the new model predictions to experimental data [58] and to fugacity-corrected Model A (Model $\mathbf{A}_{\mathrm{fc}}$ ).

Figure 3: $\mathrm{CO}_{2}$ solubility in $1 \mathrm{~mol} . \mathrm{L}^{-1}$ and $4 \mathrm{mol.} . \mathrm{L}^{-1} \mathrm{NaCl}$ solutions at $200{ }^{\circ} \mathrm{C}$ versus $\mathrm{CO}_{2}$ partial pressure $\left(\mathrm{P}_{\mathrm{CO} 2}\right)$. Comparison of the new model predictions to experimental data [59], and to fugacity-corrected Model A (Model $\mathbf{A}_{\mathrm{fc}}$ ) and Model B [51].

Figure 4: $\mathrm{pH}$ versus $\mathrm{NaCl}$ concentration at $25^{\circ} \mathrm{C}$ under 1 bar of $\mathrm{CO}_{2}$. Comparison of the new model predictions to experimental data [56], and to Model A, Model C and Model D.

Figure 5: $\mathrm{pH}$ versus $\mathrm{CO}_{2}$ partial pressure at $42{ }^{\circ} \mathrm{C}$ in pure water. Comparison of the new model predictions to experimental data [60] and to fugacity-corrected model $\mathbf{A}\left(\right.$ Model $\mathbf{A}_{\mathrm{fc}}$ ) and Model $\mathbf{E}$.

Figure 6: Results of $\mathrm{pH}$ calculations with the new model with $\mathrm{CO}_{2}$ partial pressure at different temperature and $\mathrm{NaCl}$ concentration.

Figure 7: Checked domains of validity for $\mathrm{pH}$ and solubility predictions and acceptable application domain based on the limits of thermodynamics models. 


\section{Tables}

Table 1: Parameters used for Equation (14) [35].

\begin{tabular}{|c|c|c|c|}
\hline Acid gas $i$ & $A_{i}$ & $B_{i}\left(\mathrm{~K}^{-1}\right)$ & $C_{i}\left(\mathrm{~K}^{-2}\right)$ \\
\hline $\mathrm{H}_{2} \mathrm{~S}$ & -2.25054 & $5.98511 \times 10^{3}$ & $-1.23934 \times 10^{6}$ \\
\hline $\mathrm{CO}_{2}$ & $-6.02700 \times 10^{-1}$ & $5.85739 \times 10^{3}$ & $-1.23934 \times 10^{6}$ \\
\hline
\end{tabular}

Table 2: References of Pitzer parameters used in this work.

\begin{tabular}{|c|c|c|}
\hline $\begin{array}{c}\text { Pitzer parameters } \beta^{(0)} \text {, } \\
\beta^{(1)}, \beta^{(2)}, C^{\Phi} \text { and } \psi\end{array}$ & Reference & Validity domain \\
\hline $\mathrm{H}^{+} / \mathrm{Cl}^{-}$ & [45] & $273 \mathrm{~K}<T<523 \mathrm{~K}, P<400 \mathrm{bar}$ \\
\hline $\mathrm{Ca}^{2+} / \mathrm{Cl}^{-}$ & [46] & $298 \mathrm{~K}<T<523 \mathrm{~K}$ \\
\hline $\mathrm{Ca}^{2+} / \mathrm{HCO}_{3}^{-}$ & [47] & $273<T<523 \mathrm{~K}, P<1000$ bar \\
\hline $\mathrm{Ca}^{2+} / \mathrm{CO}_{3}{ }^{2-}$ & [47] & $273<T<523 \mathrm{~K}, P<1000$ bar \\
\hline $\mathrm{Ca}^{2+} / \mathrm{HO}^{-}$ & [48] & not reported \\
\hline $\mathrm{Na}^{+} / \mathrm{Cl}^{-}$ & [43] & $273 \mathrm{~K}<T<573 \mathrm{~K}, P<1000$ bar \\
\hline $\mathrm{Na}^{+} / \mathrm{HCO}_{3}^{-}$ & [49] & $273<T<523 \mathrm{~K}$ \\
\hline $\mathrm{Na}^{+} / \mathrm{OH}^{-}$ & [50] & $273 \mathrm{~K}<T<623 \mathrm{~K}, P<400$ bar \\
\hline $\mathrm{Na}^{+} / \mathrm{CO}_{3}{ }^{2-}$ & [49] & $273<T<523 \mathrm{~K}$ \\
\hline $\mathrm{Cl}^{-} / \mathrm{CO}_{2}$ & [51] & $273 \mathrm{~K}<T<533 \mathrm{~K}, P<2000$ bar \\
\hline $\mathrm{HCO}_{3}^{-} / \mathrm{CO}_{2}$ & [52] & $310<T<470 \mathrm{~K}$ \\
\hline $\mathrm{Ca}^{2+} / \mathrm{CO}_{2}$ & [47] & $273<T<523 \mathrm{~K}, P<1000$ bar \\
\hline $\mathrm{Na}^{+} / \mathrm{CO}_{2}$ & [51] & $273 \mathrm{~K}<T<533 \mathrm{~K}, P<2000 \mathrm{bar}$ \\
\hline $\mathrm{Na}^{+} / \mathrm{H}_{2} \mathrm{~S}$ & [53] & $298 \mathrm{~K}<T<623 \mathrm{~K}$ \\
\hline $\mathrm{HS}^{-} / \mathrm{H}_{2} \mathrm{~S}$ & [54] & $313<T<393 \mathrm{~K}, 100$ bar \\
\hline $\mathrm{H}_{2} \mathrm{~S} / \mathrm{Na}^{+} / \mathrm{Cl}^{-}$ & [53] & $298 \mathrm{~K}<T<623 \mathrm{~K}$ \\
\hline $\mathrm{Ca}^{2+} / \mathrm{Cl}^{-} / \mathrm{CO}_{2}$ & [55] & $T<363 \mathrm{~K}$ \\
\hline $\mathrm{H}_{2} \mathrm{~S} / \mathrm{Na}^{+} / \mathrm{Cl}^{-}$ & [53] & $298 \mathrm{~K}<T<623 \mathrm{~K}$ \\
\hline $\mathrm{Ca}^{2+} / \mathrm{Cl}^{-} / \mathrm{CO}_{2}$ & [55] & $T<363 \mathrm{~K}$ \\
\hline $\mathrm{Na}^{+} / \mathrm{Cl}^{-} / \mathrm{CO}_{2}$ & [51] & $273 \mathrm{~K}<T<533 \mathrm{~K}, P<2000$ bar \\
\hline
\end{tabular}


Table 3: Other models to which the new model was compared.

\begin{tabular}{|c|c|c|c|}
\hline $\begin{array}{c}\text { In-text } \\
\text { designation }\end{array}$ & Usual designation, features & $\begin{array}{l}\text { Claimed validity } \\
\text { (if known) }\end{array}$ & Reference \\
\hline New model & $\begin{array}{l}\text { this work, using Pitzer for } \\
\text { activity coefficients in the liquid } \\
\text { phase and Soreide and Witson } \\
\text { for fugacity coefficients of } \\
\text { gqseous components. }\end{array}$ & $\begin{array}{l}5 \text { to } 200^{\circ} \mathrm{C} \\
0 \text { to } 5 \text { mol. } \mathrm{L}^{-1}\end{array}$ & $\begin{array}{l}\text { This } \\
\text { work }\end{array}$ \\
\hline Model A & $\begin{array}{l}\text { Corplus, Total, using empirical } \\
\text { equilibrium constants. }\end{array}$ & $\begin{array}{c}5 \text { to } 120^{\circ} \mathrm{C} \\
0 \text { to } 20 \text { bar } \mathrm{CO}_{2} \\
\text { (partial pressure) } \\
0 \text { to } 0.75 \text { mol. } \text { L }^{-1}\end{array}$ & {$[22,23]$} \\
\hline Model $\mathrm{A}_{\mathrm{fc}}$ & $\begin{array}{l}\text { Model A with the fugacity of } \\
\mathrm{CO}_{2} \text { and } \mathrm{H}_{2} \mathrm{~S} \text { gases as inputs }\end{array}$ & & l \\
\hline Model B & $\begin{array}{l}\text { Duan and Sun model, using } \\
\text { Pitzer for activities and Duan et } \\
\text { al. for fugacities }\end{array}$ & $\begin{array}{c}0 \text { to } 350{ }^{\circ} \mathrm{C} \\
0 \text { to } 2000 \mathrm{bar} \\
0 \text { to } 4.3 \mathrm{~mol} . \mathrm{L}^{-1}\end{array}$ & [51] \\
\hline Model C & BP model & not known & [56] \\
\hline Model D & Shell Model & not known & [56] \\
\hline Model E & $\begin{array}{l}\text { Norsok model, using empirical } \\
\text { equilibrium constants. }\end{array}$ & $\begin{array}{l}5 \text { to } 150{ }^{\circ} \mathrm{C} \\
0.1 \text { to } 10 \text { bar } \mathrm{CO}_{2} \\
\text { (fugacity) } \\
\text { Total pressure }< \\
1000 \mathrm{bar} \\
0 \text { to } 3 \mathrm{~mol} . \mathrm{L}^{-1}\end{array}$ & [6] \\
\hline
\end{tabular}

Table 4: Range of tested parameters in Figure 1 to Figure 5.

\begin{tabular}{|c|c|c|c|c|c|c|}
\hline Figure & $\begin{array}{c}T \\
\left({ }^{\circ} \mathrm{C}\right)\end{array}$ & $\begin{array}{l}\text { ionic strength } \\
\left(\mathrm{mol} \cdot \mathrm{L}^{-1}\right)\end{array}$ & $\begin{array}{l}P_{\mathrm{CO} 2} \\
\text { (bar) }\end{array}$ & $\begin{array}{l}P_{H 2 S} \\
\text { (bar) }\end{array}$ & $\begin{array}{l}\text { total pressure } \\
\text { (bar) }\end{array}$ & $\mathrm{pH}$ \\
\hline 1 & 49 & 0 & $0-42$ & $0-133$ & $0-700$ & no \\
\hline 2 & $40-160$ & 4 & $5-90$ & no & $5-90$ & no \\
\hline 3 & 200 & $1-4$ & $0-2000$ & no & $0-2000$ & no \\
\hline 4 & 25 & $0-4.25$ & 1 & no & 1 & yes \\
\hline 5 & 42 & 0 & $0-350$ & no & $0-350$ & yes \\
\hline
\end{tabular}




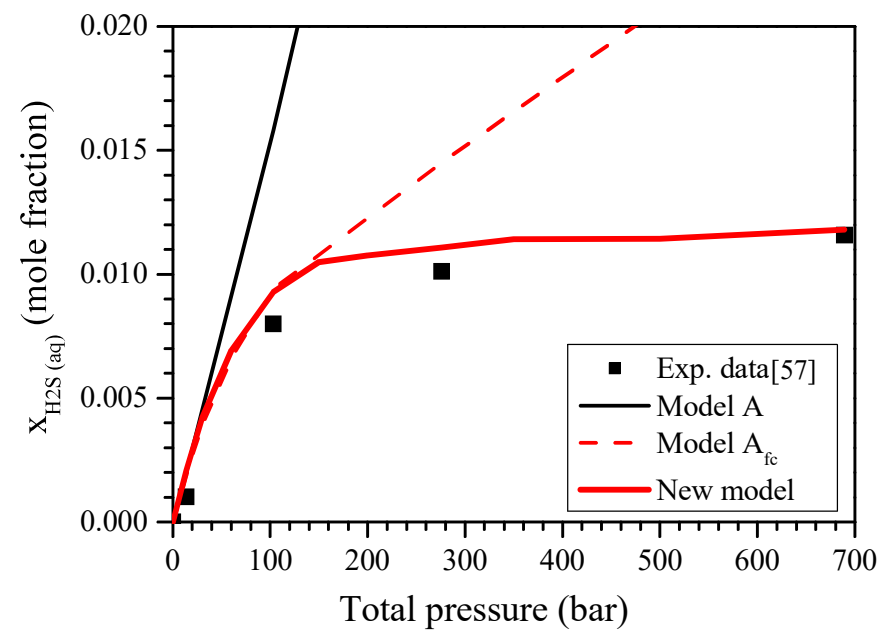

Figure 1: $\mathrm{H}_{2} \mathrm{~S}$ solubility in pure water versus total pressure of a $75 \% \mathrm{CH}_{4}-\mathrm{C}_{3} \mathrm{H}_{8}(95: 5$ mole ratio) and $25 \%$ $\mathrm{H}_{2} \mathrm{~S}-\mathrm{CO}_{2}$ (3:1 mole ratio) gas mixture at $49^{\circ} \mathrm{C}$. Comparison of the new model predictions to experimental data [57] and to Model A and fugacity-corrected model A (Model Afc). 


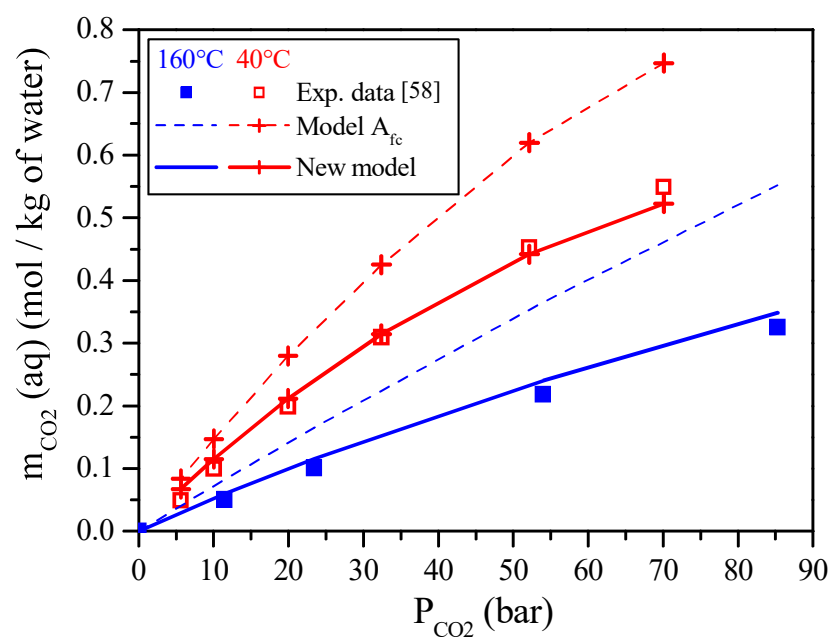

Figure 2: $\mathrm{CO}_{2}$ solubility in $4 \mathrm{~mol} . \mathrm{kg}^{-1} \mathrm{NaCl}$ solution versus $\mathrm{CO}_{2}$ partial pressure at $40{ }^{\circ} \mathrm{C}$ and $160{ }^{\circ} \mathrm{C}$. Comparison of the new model predictions to experimental data [58] and to fugacity-corrected Model A (Model $\mathbf{A}_{\text {fc }}$ ). 


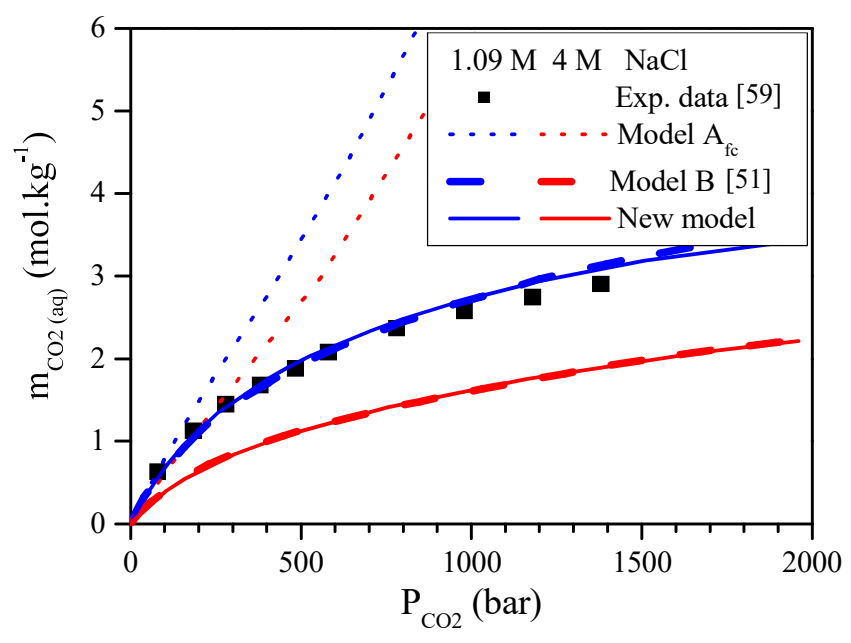

Figure 3: $\mathrm{CO}_{2}$ solubility in 1 mol.L $\mathrm{L}^{-1}$ and 4 mol. $\mathrm{L}^{-1} \mathrm{NaCl}$ solutions at $200{ }^{\circ} \mathrm{C}$ versus $\mathrm{CO}_{2}$ partial pressure $\left(\mathrm{P}_{\mathrm{CO} 2}\right)$. Comparison of the new model predictions to experimental data [59], and to fugacity-corrected Model A (Model $\mathbf{A}_{\mathrm{fc}}$ ) and Model B [51]. 


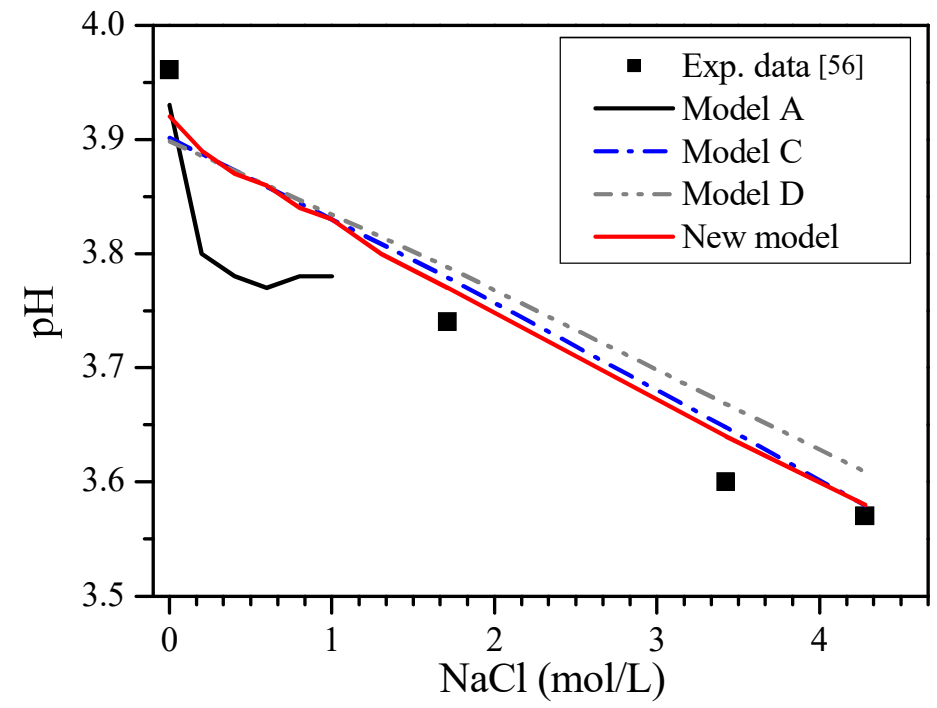

Figure 4: $\mathrm{pH}$ versus $\mathrm{NaCl}$ concentration at $25^{\circ} \mathrm{C}$ under 1 bar of $\mathrm{CO}_{2}$. Comparison of the new model predictions to experimental data [56], and to Model A, Model C and Model D. 


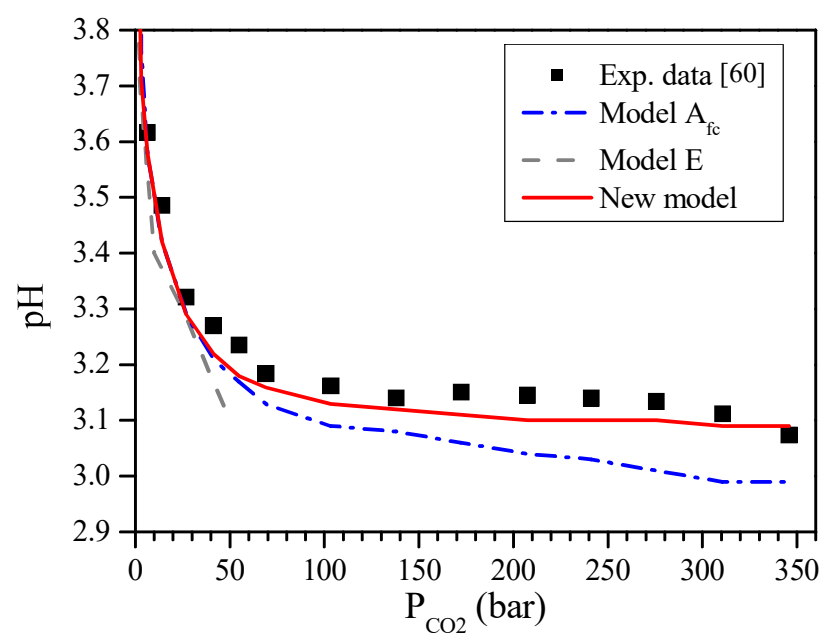

Figure 5: $\mathrm{pH}$ versus $\mathrm{CO}_{2}$ partial pressure at $42{ }^{\circ} \mathrm{C}$ in pure water. Comparison of the new model predictions to experimental data [60] and to fugacity-corrected model A (Model $\left.\mathbf{A}_{\mathrm{fc}}\right)$ and Model $\mathrm{E}$. 
Figure 6

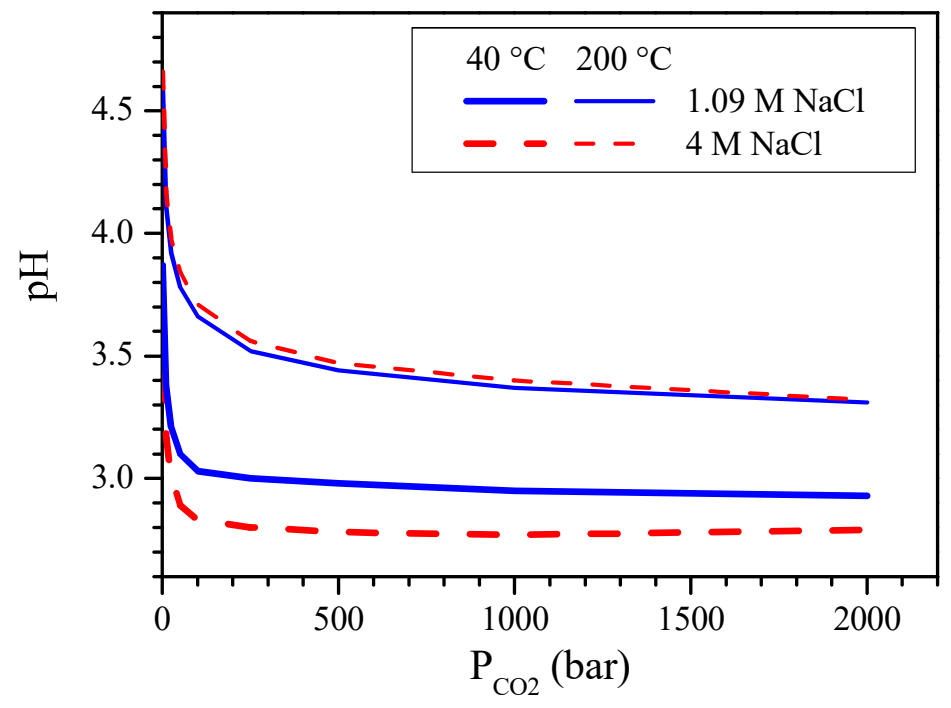

Figure 6: Results of $\mathrm{pH}$ calculations with the new model with $\mathrm{CO}_{2}$ partial pressure at different temperature and $\mathrm{NaCl}$ concentration. 


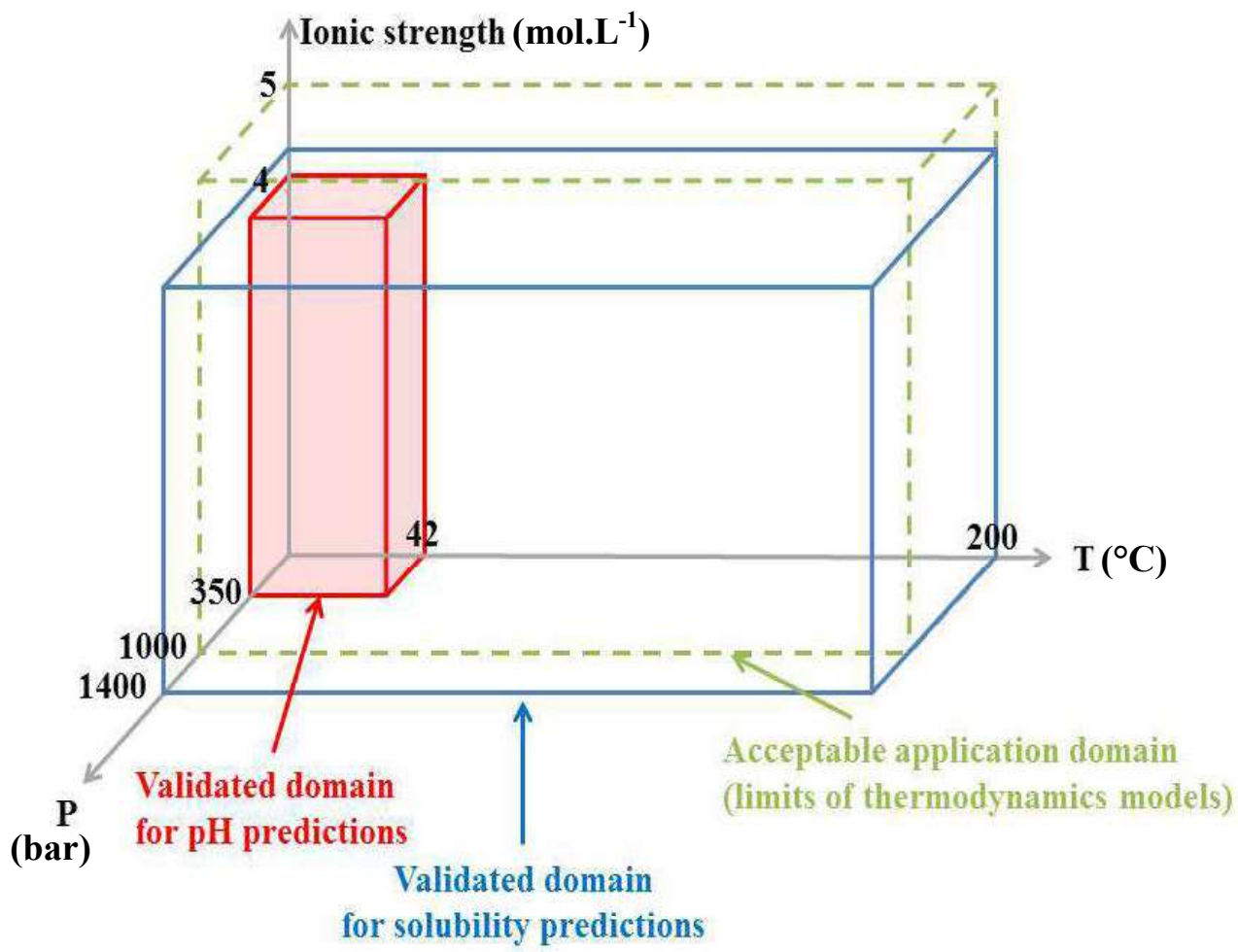

Figure 7: Checked domains of validity for $\mathrm{pH}$ and solubility predictions and acceptable application domain based on the limits of thermodynamics models. 